\title{
MUCOPOLYSACCHARIDE CONTENT OF SKIN IN PATIENTS WITH PRETIBIAL MYXEDEMA*†
}

\author{
By WILLIAM H. BEIERWALTES and ALFRED JAY BOLLET $\ddagger$ \\ (From the Department of Internal Medicine, University of Michigan Medical School and \\ Wayne State University College of Medicine, Ann Arbor and Detroit, Mich.)
}

(Submitted for publication December 15, 1958; accepted February 26, 1959)

It is well-known that the skin of patients with primary and secondary myxedema contains a mucinous infiltrate. This extracellular deposition of metachromatically staining material has been interpreted as being a complex of acid mucopolysaccharide and protein (1). It has not been defined chemically. The infiltrate disappears from the skin of patients with generalized myxedema who are given 120 to $180 \mathrm{mg}$. of desiccated thyroid daily for six to eight weeks (1). A deposit, histochemically like that which occurs in generalized myxedema, occasionally presents locally in the pretibial skin of patients with thyrotoxicosis and exophthalmos $(2,3)$. When the patient with localized pretibial myxedema is given $180 \mathrm{mg}$. of desiccated thyroid a day, however, no clinical or histochemical change occurs in the myxedematous plaque.

In 1947 Watson and Pearce isolated a crude mucopolysaccharide fraction from the pretibial plaques of two patients with pretibial myxedema. They found considerably less of this material in skin from the amputated leg of an elderly man (4). We have found no record of the comparison of chemical or histochemical findings of myxedematous areas to other areas of the skin of patients with pretibial myxedema, or comparison with control patients of similar age.

We wish to report a chemical study of the mucopolysaccharide concentration of the skin of six euthyroid patients with pretibial myxedema and exophthalmos and eight patients of comparable

\footnotetext{
* Presented at the Meeting of the Central Society for Clinical Research, November 1, 1958, Chicago, Ill.

$\dagger$ This work was supported in part by the Research and Service in the Utilization of Human ResourcesThyroid Hormone Research Fund; the American Cancer Society; the Michigan Memorial Phoenix Project; the Michigan Chapter of the Arthritis and Rheumatism Foundation; and the Receiving Hospital Research Corporation.
}

$¥$ John and Mary Markle Scholar in Medical Science. sex distribution and mean age without thyroid disease. The acid mucopolysaccharide content of the myxedematous areas was found to be considerably elevated when compared to clinically uninvolved skin from the same patients. The clinically uninvolved areas were found to contain a moderately increased concentration of acid mucopolysaccharide when compared to normal skin from patients without thyroid disease.

\section{METHOD}

Under local anesthesia skin biopsies were taken from four women and two men, 27 to 58 years of age, with extensive pretibial myxedema associated with exophthalmos manifested by increased exophthalmometer measurements or by serious collateral eye signs. Biopsies were obtained from the affected pretibial skin and an area of clinically uninvolved skin of the upper thigh and occasionally from the deltoid area of the shoulder. The clinical story and histology of previous skin biopsies of three of these patients were summarized in 1954 (2).

Skin biopsies were also obtained on six females and two males, six and one-half to 78 years of age, who had no demonstrable thyroid disease or pretibial myxedema, past or present. These biopsies were obtained from the skin of the leg at the time of orthopedic surgery.

Details of the method of assay of acid mucopolysaccharide used in this study have been published by Bollet (5). Values are expressed as micrograms of uronic acid in the acid mucopolysaccharide fraction per $100 \mathrm{mg}$. of dried, fat free tissue; carbazole and orcinol methods of determination were used. This procedure was demonstrated to have a replicate reproducibility of approximately \pm 7 per cent.

\section{RESULTS}

The acid mucopolysaccharide concentrations of the clinically myxedematous pretibial skin are presented in Table I, A. The mean value was $990 \mu \mathrm{g}$. of uronic acid per $100 \mathrm{mg}$. of tissue using the carbazole method, and $735 \mu \mathrm{g}$. using orcinol. The mean values for the clinically uninvolved areas of skin from the same individuals were 171 and $146 \mu \mathrm{g}$. per $100 \mathrm{mg}$. of tissue, respectively 
TABLE I

Uronic acid content of the acid mucopolysaccharide fraction of skin biopsies of patients with pretibial myxedema, using carbazole and orcinol methods of determinations*

\begin{tabular}{|c|c|c|c|}
\hline Patient & Carbazole & Orcinol & $\begin{array}{l}\text { Ratio of } \\
\text { carbazole } \\
\text { to orcino } \\
\text { values }\end{array}$ \\
\hline \multicolumn{4}{|c|}{ A. Myxedematous areas (pretibial) } \\
\hline $\begin{array}{l}1 \\
2 \\
3 \\
4 \\
5 \\
6\end{array}$ & $\begin{array}{r}1,770 \\
2,010 \\
804 \\
408 \\
440 \\
507\end{array}$ & $\begin{array}{r}1,733 \\
1,524 \\
519 \\
146 \\
298 \\
298\end{array}$ & $\begin{array}{l}1.0 \\
1.3 \\
1.6 \\
2.8 \\
1.5 \\
1.7\end{array}$ \\
\hline Mean & 990 & 753 & 1.7 \\
\hline \multicolumn{4}{|c|}{ B. "Normal" areas } \\
\hline $\begin{array}{l}1 \text { (thigh) } \\
2 \text { (thigh) } \\
\text { (shoulder) } \\
3 \text { (shoulder) } \\
4 \text { (thigh) } \\
5 \text { (thigh) } \\
6 \text { (thigh) }\end{array}$ & $\begin{array}{l}98.7 \\
221 \\
303 \\
108 \\
145 \\
184 \\
138\end{array}$ & $\begin{array}{l}126 \\
180 \\
183 \\
95.5 \\
141 \\
164 \\
129\end{array}$ & $\begin{array}{l}0.8 \\
1.2 \\
1.3 \\
1.1 \\
1.0 \\
1.1 \\
1.2\end{array}$ \\
\hline Mean & 171 & 146 & 1.1 \\
\hline
\end{tabular}

* Results are expressed as micrograms of uronic acid per $100 \mathrm{mg}$. of dried, fat free skin.

(Table I, B). The latter values were higher than the mean values found in the normal skin of eight individuals, which were 89 and $98 \mu \mathrm{g}$. per 100 mg., respectively (Table II). The differences in carbazole values from clinically uninvolved skin of patients with pretibial myxedema as compared to skin from control patients without thyroid disease are significant, with a $\mathrm{p}$ value of $<0.01$.

TABLE II

Uronic acid content of the mucopolysaccharide fraction of biopsies of skin of subjects without thyroid disease, using carbazole and orcinol methods of determination *

\begin{tabular}{lccc}
\hline \hline & Carbazole & Orcinol & $\begin{array}{c}\text { Ratio of } \\
\text { carbazole } \\
\text { to orcinol } \\
\text { values }\end{array}$ \\
\hline Patient & 95.2 & 125 & 0.8 \\
2 (shin) & 93.0 & 97 & 1.0 \\
3 (shin) & 64.6 & 81.4 & 0.8 \\
4 (thin) & 78.6 & 115 & 0.7 \\
5 (shin) & 90.0 & 60.5 & 1.5 \\
6 (thigh) & 67.8 & 70.7 & 1.0 \\
7 (thigh) & 104 & 115 & 0.9 \\
8 (shin) & 115 & 115 & 1.0 \\
Mean & 89 & 98 & 1.0 \\
\hline
\end{tabular}

* Results are expressed as micrograms of uronic acid per $100 \mathrm{mg}$. of dried, fat free skin.
Other variables that might affect these data were examined. The mean age of the normal controls was 48 years as compared to a mean age of 45 years in patients with thyroid disease. No correlation was found between age and acid mucopolysaccharide value in patients within either group.

Table III presents a comparison of some clinical features with the acid mucopolysaccharide concentration found in the areas of pretibial myxedema by the carbazole method.

Mucopolysaccharide levels were lower in the three patients with the lesions of longest duration. The areas of pretibial myxedema in these patients were observed to be diminishing. In ad-

TABLE III

$A$ comparison of some clinical features of patients with pretibial myxedema

\begin{tabular}{|c|c|c|c|}
\hline $\begin{array}{l}\text { Duration } \\
\text { of pretibial } \\
\text { myxedema }\end{array}$ & $\begin{array}{l}\text { Carbazole } \\
\text { value }\end{array}$ & $\begin{array}{l}\text { Exophthal- } \\
\text { mometer } \\
\text { measurements } \\
\text { at the time } \\
\text { of biopsy }\end{array}$ & $\begin{array}{l}\text { History of thyroid } \\
\text { disease* }\end{array}$ \\
\hline $\begin{array}{c}\text { years } \\
0.33 \\
1.8 \\
2.5 \\
4.0 \\
10.0 \\
13.0\end{array}$ & $\begin{array}{c}\mu g . / 100 \mathrm{mg} . \\
1,770 \\
2,010 \\
804 \\
408 \\
440 \\
507\end{array}$ & $\begin{array}{c}\mathrm{mm} . \\
16.5 / 17.5 \\
21.5 / 20.5 \\
17 / 18 \\
24 / 24 \\
24.5 / 27.5 \\
23 / 24\end{array}$ & $\begin{array}{l}\text { Th., Tx., Eu., T. } \\
\text { Th., I Is1, Eu. } \\
\text { Th., Tx., Eu., T. } \\
\text { Th., Tx., on thyroid } \\
\text { Th., I'11, on thyroid } \\
\text { Th., Tx., on thyroid }\end{array}$ \\
\hline
\end{tabular}

* Th., thyrotoxicosis; Tx., surgical thyroidectomy; ${ }^{131}$, $I^{131}$ thyroidectomy; Eu., euthyroid; and T., previously on thyroid medication.

dition, these patients had been receiving desiccated thyroid for at least four years. It should be noted, however, that Patients 1 and 3 had also been on desiccated thyroid from the onset of pretibial myxedema until a few weeks before biopsy. Exophthalmometer measurements were higher in patients with thyroid disease of longer duration. It is of particular interest that $\mathrm{Pa}$ tients 1 and 3, the two patients with least protrusion of the eyes, were the only pretibial myxedema patients in whom values for acid mucopolysaccharide in skin of thigh overlapped mucopolysaccharide values in leg skin from patients without thyroid disease. The acid mucopolysaccharide concentration did not seem to be related to the history of surgery or radioactive iodine treatment for relief of thyrotoxicosis. 
Higher acid mucopolysaccharide levels in association with pretibial myxedema were accompanied by a higher mean ratio of carbazole to orcinol values.

\section{DISCUSSION}

Curtis, Cawley and Johnwick in 1949 reported the association of malignant exophthalmos and pretibial myxedema and suggested that both the malignant exophthalmos and the localized myxedema might be caused by a local effect of pituitary thyroid stimulating hormone (TSH) on the extraocular tissues and on the corium of the skin of the lower leg (6). We have demonstrated that the administration of TSH to dogs results in increase in concentration of acid mucopolysaccharide in the dog thyroid gland (7). The generalized increase in the concentration of acid mucopolysaccharide in the skin of patients with pretibial myxedema might also result from the same stimulus. Differences in concentration might be explained by local variations in tissue responsiveness and to physical factors such as gravity and tissue pressure. The increased concentration of acid mucopolysaccharide demonstrated histochemically in the retro-orbital tissues of coincident exophthalmos is presumably part of this response (3). Since pretibial myxedema can occur with either hypo- or hyperthyroidism (2), and since our patients were euthyroid at the time biopsies were obtained, it seems unlikely that lack of thyroid hormone is the causative factor of this condition, although evidence would seem to indicate that it is the causative factor in generalized myxedema. The observation that localized myxedema in one patient with coincident exophthalmos disappeared completely with the onset of pituitary failure after pituitary surgery is evidence for a possible role of TSH in the etiology of localized myxedema (8). These two states with similar histochemical findings thus appear to differ in some important aspects.

The increase in the carbazole to orcinol ratio found in the myxedematous areas suggests a qualitative change in the mucopolysaccharide of the skin. The ratio of 1.7 to 1 found approaches the 2 to 1 ratio characteristic of heparitin sulfate
(5), and suggests a predominant increase in this type of polysaccharide.

The finding that the changes in mucopolysaccharide content of the skin are not limited to the pretibial area indicates that the term "localized pretibial myxedema" may be clinically correct, but is chemically incorrect.

\section{SUMMARY}

A chemical assay of the skin of six patients with "localized" pretibial myxedema was made. All six patients had exophthalmos and were euthyroid at the time the skin biopsies were made. Biopsies were made of the clinically involved skin of the shin and of clinically uninvolved skin of the upper leg and the deltoid area. The acid mucopolysaccharide concentration of these skin specimens was compared with the concentration found in the leg skin biopsies obtained during orthopedic operations on eight comparable individuals who had never had thyroid disease.

The mean value for acid mucopolysaccharide concentration in the clinically myxedematous pretibial skin was $990 \mu \mathrm{g}$. of uronic acid per 100 mg. of tissue using the carbazole method, and $753 \mu \mathrm{g}$. using orcinol. The mean values for the clinically uninvolved areas of skin from the same individuals were 171 and $146 \mu \mathrm{g}$. per $100 \mathrm{mg}$. of tissue, respectively. The latter values are higher than the mean values found in the normal skin of eight individuals without thyroid disease, which were 89 and $98 \mu \mathrm{g}$. per $100 \mathrm{mg}$., respectively.

Higher acid mucopolysaccharide values found in pretibial myxedema were associated with a higher mean ratio of carbazole to orcinol values.

\section{REFERENCES}

1. Gabrilove, J. L., and Ludwig, A. W. The histogenesis of myxedema. J. clin. Endocr. 1957, 17, 925.

2. Beierwaltes, W. H. Clinical correlation of pretibial myxedema with malignant exophthalmos. Ann. intern. Med. 1954, 40, 968.

3. Ludwig, A. W., Boas, N. F., and Soffer, L. J. Role of mucopolysaccharides in pathogenesis of experimental exophthalmos. Proc. Soc. exp. Biol. (N. Y.) 1950, 73, 137.

4. Watson, E. M., and Pearce, R. H. The mucopolysaccharide content of the skin in localized (pre- 
tibial) myxedema. Amer. J. clin. Path. 1947, 17, 7. Bollet, A. J., and Beierwaltes, W. H. Acid mucopoly507.

5. Bollet, A. J. The measurement of tissue acid mucopolysaccharides. J. clin. Invest. 1958, 37, 858.

6. Curtis, A. C., Cawley, E. P., and Johnwick, E. B. Association of progressive (malignant) exophthalmos and localized myxedema. Arch. Derm. Syph. (Chicago) 1949, 60, 318. saccharide concentration in the thyroid gland. J. clin. Endocr. 1959, 19, 257.

8. McCullagh, E. P., Ruedemann, A. D., and Gardner, W. J. Exophthalmos of Graves' disease following pituitary irradiation, orbital decompression and electrocautery to the pituitary gland. Trans. Amer. Goiter Ass. 1942-46, p. 30. 